\title{
Investigating the Effect of Advertising on Emotional Reactions of Customers (Case Study: Branches of Parsian Bank in Tehran)
}

\author{
Hojjat Soheyli Rad* \\ No 19, Sadi Sterrt, Urmia-5787737498, Iran \\ Received 22 June 2018, Accepted 24 Aug 2018, Available online 26 Aug 2018, Vol.8, No.4 (July/Aug 2018)
}

\begin{abstract}
At the current word and in the industrial and even post-industrial age, advertising is a need. Advertising mixed of science and art can be called also as miracle industry and an industry, which can recover the industry and can also destroy industry, if it is used in wrong way. Commercial advertising, with use of modern media that are being more variable and effective over the time with wonderful speed, is not a simple marketing or notification to link consumers and suppliers anymore and is in fact a reality that can leave deep and fundamental effects on domains of human social life and on human. Therefore, the present study has investigated the effect of advertising on emotional reactions of customers in branches of Parsian Bank in Tehran. Statistical population in this study consists of customers of all branches of Parsian Bank in Tehran. Using Morgan table, 146 people were selected as sample using simple random sampling method. Data analysis was done using SPSS22 and Lisrel8.8 software. The results of the study showed that there is significant correlation between advertising and emotional reactions of customers. Moreover, the results showed that there is significant correlation between brand promotion in advertising, related news in advertising, and empathy in advertising, familiarity with advertising, confusion in advertising, and entertainment in advertising with customer emotional reactions. Moreover, there is significant correlation between enjoyable emotional reactions of customers to advertising and advantage-based value and hedonic value.
\end{abstract}

Keywords: advertising, emotional reactions, brand promotion, empathy in advertising, advantage-based value, hedonic value

\section{Introduction}

At the today's world and in industrial and even postindustrial age, advertising is a need. Advertising mixed of science and art can be called also as miracle industry and an industry, which can recover the industry and can also destroy industry, if it is used in wrong way. Undoubtedly, advertising can be the most prevalent part of mixed promotion, which can be a strong power for change. The clear goals and careful planning can be success key of an advertisement. Advertising can be important instrument in progress of sales. Advertising is one of the most common instruments used by companies to conduct encouraging communications towards buyers and target communities. Transparent goals and careful planning can be success keys of an advertisement. Advertising can be important in progress of sales. Advertisements are messages encompassing all relevant activities of impersonal, commodity or video introduction (or both of them) supported by a person or organization in relation to a commodity, service or an idea. The today's life at

*Corresponding author's ORCID ID: 0000-0000-0000-0000 DOI: https://doi.org/10.14741/ijcet/v.8.4.26 modern societies is full of advertising messages affecting human life in various frames. The importance of this issue is that advertising can be multidimensional phenomenon and is not just video phenomenon because of possibility of simultaneous use of picture, words, moving picture and sound.

Suitable advertising plans can lead to favorable results such as gaining more benefit through more selling; although the plans are cost-consuming. If advertising plans make company achieve its goals, the company can then manage its costs and profit and this can be considered as an investment (Ha et al, 2011).

According to intense competition among companies and rapid growth of markets and also rapid changes in behavior of consumers; advertisements can be considered as main instruments in providing knowledge and awareness in consumers about products and services. Accordingly, advertising can't be considered as an instrument to increase sales of company (Hsu and Lin, 2008). Companies need effective and efficient ways to make relationship with customers more than before to enhance their selling All companies in field of business tend to find methods, using which they can change attitude of consumers to 
positive attitude towards the companies, so that they can increase their opportunity to enhance their online sales (Altona, 2009). Pilling and White (2009) have claimed that attitude of customers towards online shopping has gained many attentions in relevant literature and can be considered as the most underlying issue from this perspective. One of the instruments to promote marketing is advertising. Media play key role in using this instrument. With innovation of experts, advertising via web has also entered to this domain as new, available and costeffective approach with high reaction rate (Marisao et $a l$, 2007). If managers are almost aware of this issue, it can help them to provide required domains to show response with advertising feedback before losing the customers (Chen et al, 2010). If it is not clear that advertising to what extent can affect affairs of companies, the customers may be surprised and the company may be unable to show response to needs of customers. This can cause distrust of users and old and new customers. Therefore, it would be better for managers to consider effectiveness of advertising before doing any kind of advertisement (Kuisma et al, 2010). In this regard, video designed messages of advertising in marketing of business companies can be used as one of the promotional instruments. Because of growth of internet as a marketing tool, using modern advertising services and web advertising in top of that is being developed (Chen, 2010). Promotion of advertisements and increasing welcoming of the media over the world has provided good context to advertise products and services and has also paved the way for direct connection of marketers and consumers without time and place limitations (Almendros and Garcia, 2014). Customer need has varied due to living conditions and change in customer attitude towards the way of taking daily affairs and machinery life has in fact led to variability of needs and this can be considered an opportunity and sometimes a threat to business companies. It can be threat, because staying away from innovative field of services provided for customers and inefficiency of these services can cause distrust and lack of positive attitude of customers towards this system (Kuisma et al, 2010). This study has investigated the impact of advertising on emotional reactions of customers in Parsian Bank Branches in Tehran.

\section{Theoretical background and research literature}

The age of technology and product and service supply needs proper management of marketing and advertising affairs to be successful among business competitors. Commercial advertising can be one of the main success factors of a product or service and they can be introduced to all people through advertising. Today, advertising has been changed into an industry and a technique and every company or organization that is more successful in using that can take more market share. Nowadays, advertising has been internationalized and companies tend to pass over the national borders and reach international markets more than before. As companies tend to find new markets and sell their products in wide regions of the worlds, they have to advertise their products in these regions (Edward, 2011). Advertising can also have significant effect on social relations of people. In fact, advertising is a kind of communication, a comprehensive communication, which can even affect social structure and can also make people come close to each other or go away from each other in terms of culture $\mathrm{CHu}$, 2012). Each advertising message uses an attraction to gain attention of audience to the content of message and to make a response on behalf of audience and viewer of advertisement. Attractiveness of advertising message is a field considered in an advertisement to encourage consumers to remind the advertisement and make decision to buy that product. The most common attractions used in advertising messages can be divided to two general groups of logical and emotional attractions (Dehdashti, 2009).

Kordloo et al (2015) conducted a study aimed at investigating the causal relation of beliefs, attitude to advertising through sports and attitude to public advertisements using structural equation modeling. The results showed that beliefs of people about advertising through sport can affect attitude of people towards public advertisements. Moreover, believe in being economic has higher discrimination power than other beliefs to discriminate attitude of people towards advertisements through sport. According to this study, some solutions can be provided to determine effective strategy of advertisement through sports.

Behnam et al (2015) conducted a study under the title of the impact of advertising attractiveness on future decision and attitude to consumer advertisement in sport services. The results showed that the main effect of advertising attractiveness on future decision in trials observed emotional advertising was more than those observed cognitive advertising.

Bahreinizadeh et al (2014) conducted a study under the title of the impact of drivers and individual factors affecting attitude to mobile advertisement with case study of mobile phone users. According to results of path analysis, the correlation between model variables was analyzed and it was found that indices such as social influence, being innovative, mobile phone technology level and overall attitude of person towards advertisements can have significant and positive effect on attitude towards mobile advertisement; although individual knowledge can have negative effect on attitude towards mobile advertisements.

Chang (2014) conducted a study under the title of the impact of comic ads on brand popularity and the impacts of advertisements on Taiwan's Tourism Industry and found that comic advertisements can affect brand awareness. Brand awareness can have also significant effect on ads attitude and brand attitude. 
Chawing et al (2011) conducted a study under the title of information processing style, attitude towards ads and brand: case study of Telecommunication Services of China and found that emotional advertising can help improvement of positive attitude towards brand. Moreover, information processing style can affect ads knowledge and brand attitude. Emotional advertising is more efficient than logical ads in terms of the impact of ads perception in brand attitude.

Tu et al (2011) conducted a study under the title of the impact of productive innovation and attractions of ads on customer attitude to ads in Taiwan and found that those ads using innovative content and topics can be more effective in customer attitude to ads compared to those with logical attractions.

Ha et al (2011) analyzed the impacts of advertising expenses on brand loyalty in field of services. As expenses of advertising can affect quality of services or products, its role should be integrated with brand loyalty indirectly. Applicable results of the study showed that expenses of advertising can affect brand loyalty directly. Moreover, advertising expenses can have positive and direct effect on perceived quality (Ha et al, 2011).

Boil et al (2011) conducted a study to investigate the role of two key marketing activities (ads and promotion of sales) to make brand equity among real consumers in the U.S and also studied the correlation between dimensions of brand equity. Applicable results of the study showed that attitude of people towards ads is important while creation of brand equity and perceived advertising expenses can have also positive effect on brand knowledge. Finally, the results show that brand knowledge can have also positive effect on perceived quality and brand image, which can also affect brand loyalty. Therefore, marketing managers and brand managers should be careful about impacts of promotional activities on consumer perception of brand equity (Boil et al, 2011).

\section{Methodology}

The present study has investigated the effect of advertising on emotional reactions of customers in Parsian Bank Branches in Tehran. Statistical population in this study consists of all customers of Parsian Bank Branches in Tehran. Using Morgan table, 146 people were selected as sample using simple random sampling. For purpose of sampling, convenience non-probable sampling was used and sample size was estimated using Cochran formula. Relevant data of this study is relevant to first half of 2017. In this study, Pleasure-Arousal-Dominance (PAD) scale was used to measure customer emotions. Dimensions of this scale include 3 emotional dimensions of pleasure, arousal and dominance. It should be mentioned that because of extension of the discussion, this study has only considered pleasure among dimensions of PAD for measurement of customer emotions towards ads. In this study, for purpose of analysis of data obtained from questionnaire, descriptive and inferential statistics have been used. In section of descriptive statistics, mean value, frequency and frequency percent have been used to describe sample.

In this study, to test normality of research variables, Kolmogorov-Smirnov test has been used and confirmatory factor analysis (CFA) has been used to confirm or reject indices of questionnaire and structural equation modeling (SEM), SPSS, LIsrel and Pearson correlation coefficient (to test relationship between two variables) and univariate regression (to measure impact of two variables) have been used to test research hypotheses. Data analysis was done using SPSS22 and Lisrel8.8.

\section{Results}

\subsection{Descriptive statistic}

Frequency distribution of respondents has been presented in table 1.

Table 1: frequency distribution of respondents

\begin{tabular}{|c|c|c|}
\hline Age & frequency & percent \\
\hline $\begin{array}{c}\text { Between } 20 \text { and } 30 \\
\text { years }\end{array}$ & 22 & $22.3 \%$ \\
\hline $\begin{array}{l}\text { Between } 31 \text { and } 40 \\
\text { years }\end{array}$ & 58 & $36 \%$ \\
\hline $\begin{array}{l}\text { Between } 41 \text { and } 50 \\
\text { years old }\end{array}$ & 55 & $31.6 \%$ \\
\hline more than 50 years & 11 & $10.1 \%$ \\
\hline Total & 146 & 100 \\
\hline Gender & frequency & percent \\
\hline Female & 72 & $48.4 \%$ \\
\hline Male & 74 & $51.6 \%$ \\
\hline Total & 146 & 100 \\
\hline $\begin{array}{l}\text { Duration of use of } \\
\text { banking services }\end{array}$ & frequency & percent \\
\hline Under 2 years old & 4 & $8 \%$ \\
\hline 2 to 4 years & 55 & $35.2 \%$ \\
\hline 4 to 6 years & 68 & $46.9 \%$ \\
\hline More than 6 years & 11 & $9.8 \%$ \\
\hline Total & 146 & 100 \\
\hline Job & frequency & percent \\
\hline Employee & 36 & $23.3 \%$ \\
\hline Free & 35 & $26.9 \%$ \\
\hline Student & 44 & $28.2 \%$ \\
\hline Others & 31 & $21.5 \%$ \\
\hline Total & 146 & 100 \\
\hline Education & frequency & percent \\
\hline Diploma & 24 & $14.2 \%$ \\
\hline Associate Degree & 22 & $13.2 \%$ \\
\hline Bachelor & 74 & $52.8 \%$ \\
\hline MA & 26 & $19.7 \%$ \\
\hline Total & 146 & 100 \\
\hline
\end{tabular}

According to table 1 , majority of participants were in age range of 31-40 years old. According to the table, men have possessed major part of sample size. People with 4-6 years' experience of using Parsian Bank services possessed major part of sample. 


\subsection{The score of research variable structures}

With the data collected from questionnaire, for each research variable, statistics such as minimum, maximum value, mean value, $\mathrm{SD}$, skewness and kurtosis have been presented as observed in table 2 .

Table 2: Descriptive variables of research

\begin{tabular}{|c|c|c|c|c|c|c|}
\hline 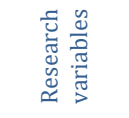 & $\underset{\Xi}{\Xi}$ & 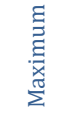 & 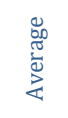 & 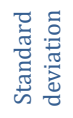 & 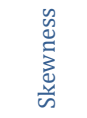 & 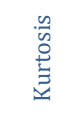 \\
\hline Advertising & 1.98 & 3.79 & 4.65 & 0.47 & -0.39 & 0.897 \\
\hline $\begin{array}{l}\text { Enjoyable } \\
\text { emotional } \\
\text { reactions }\end{array}$ & 1.78 & 3.84 & 4.58 & 0.58 & -0.258 & $0 . \overline{135}$ \\
\hline $\begin{array}{l}\text { Perceived } \\
\text { value }\end{array}$ & 1.98 & 3.54 & 4.57 & 0.56 & -0.125 & $\begin{array}{c}- \\
0.326\end{array}$ \\
\hline $\begin{array}{l}\text { Behavioral } \\
\text { tendencies }\end{array}$ & 1.95 & 5 & 4.65 & 0.53 & -0.135 & 0.457 \\
\hline
\end{tabular}

In table 2, the range of variance of scores of variables, mean value and their standard deviation is presented. Clearly, it mentioned variables are in acceptable range for two indices of skewness and kurtosis.

\subsection{Inferential statistics}

4.3.1 Kolmogorov-Smirnov (K-S) test to test normality of research variables

To test research hypotheses, the normality of variables was tested first of all. Hence, the condition was firstly studied for research variables

Table 3: Kolmogorov-Smirnov test for normality of research variables

\begin{tabular}{|c|c|c|c|c|c|}
\hline 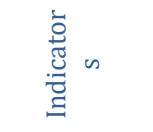 & $\begin{array}{l}\grave{d} \\
\stackrel{\Xi}{\Xi} \\
z\end{array}$ & 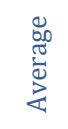 & 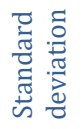 & 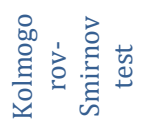 & 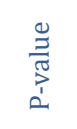 \\
\hline Advertising & 146 & 3.57 & 0.38 & 1.435 & 0.156 \\
\hline $\begin{array}{l}\text { Enjoyable } \\
\text { emotional } \\
\text { reactions }\end{array}$ & 146 & 3.56 & 0.59 & 1.258 & 0.135 \\
\hline $\begin{array}{l}\text { Perceived } \\
\text { value }\end{array}$ & 146 & 3.67 & 0.53 & 0.638 & 0.189 \\
\hline $\begin{array}{l}\text { Behavioral } \\
\text { tendencies }\end{array}$ & 146 & 3.98 & 0.97 & 1.647 & 0.136 \\
\hline
\end{tabular}

As significance level of K-S test in table 3 for research variable is higher than 0.05 , it could be found that distribution of the said variables is not significantly different from normal distribution. Hence, it could be found that distribution of research variables is normal.

\subsection{Confirmatory factor analysis (CFA)}

4.4.1 Factor analysis of research variables
In table 4, chi-squared (x2) values, df, RMSEA (Root Mean Square Error of Approximation), Comparative Fit Index (CFI), goodness of fit index (GFI) and incremental fit index (IFI) have been measured for each variables.

Table 4: Results of confirmatory factor analysis (CFA)

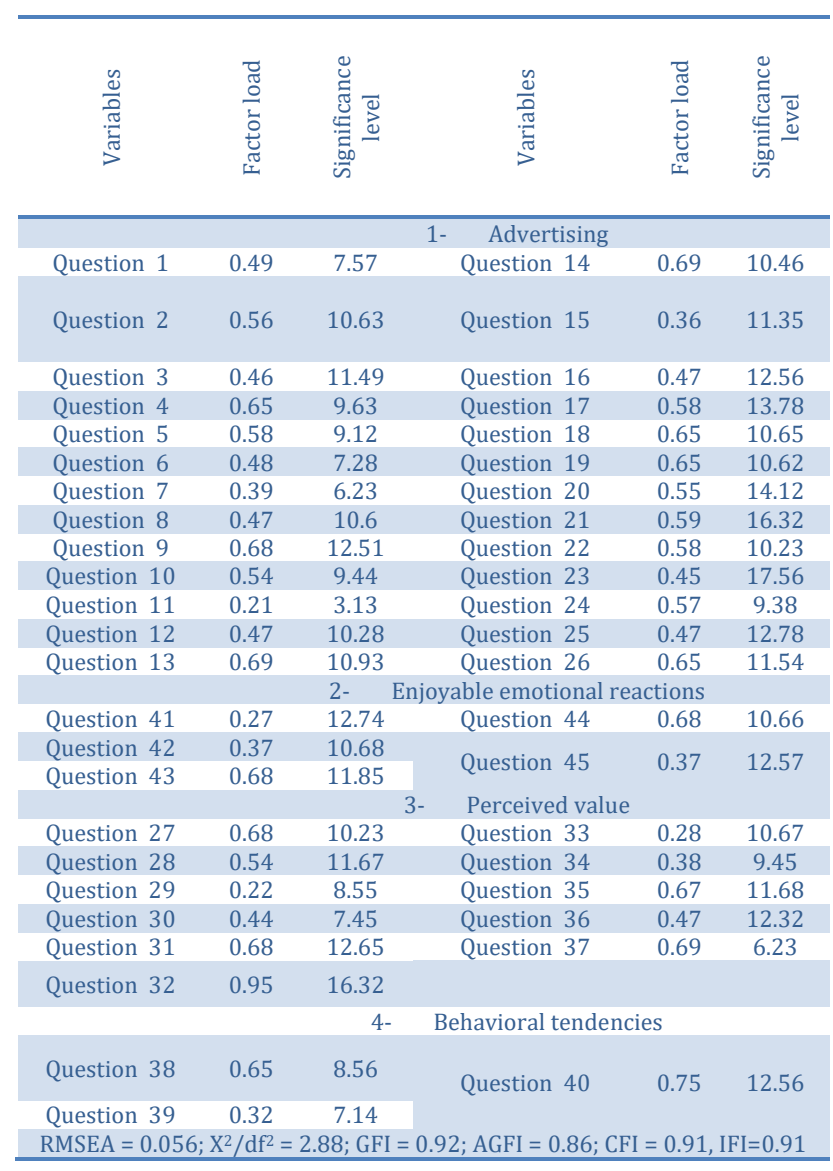

After estimation of model parameters, the question is that to what extent the proposed model is in consistence with the relevant data? Answering the question is possible just through analysis of model fitness. Therefore, the researcher should make sure of model fitness in structural equation analysis after taking estimation of parameters and before interpreting them.

Table 4 shows that CFA of constructs of questionnaire has good fitness and questionnaire constructs can show the relevant variables properly. Other values of final model are presented in table 5 :

Table 5: Final mode values

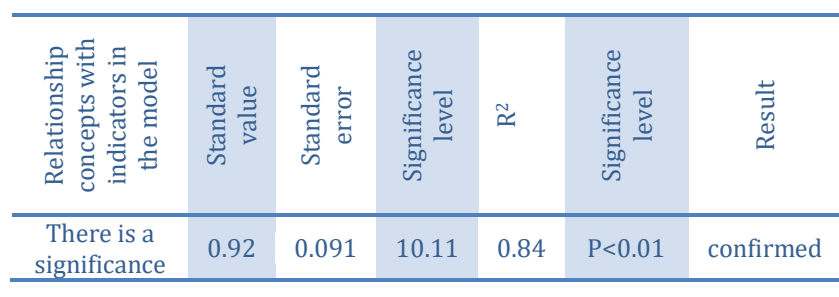

2. Chi Square Divided to Degree of Freedom 


\begin{tabular}{l}
\hline relationship \\
between \\
advertising \\
and \\
emotional \\
reactions of \\
customers \\
\hline
\end{tabular}

Significance level values, obtained by division of factor load estimation in standard error, can show significance of factor load estimation (significant difference of factor load from 0). Significance level values in range $(1.96,-1.96)$ show lack of significant effect between latent variables. Significance level in range )1.96, 3( shows significant effect with confidence level higher than $95 \%$ between relevant latent variables. Significance level values $(\geq 3)$ show significant effect at the confidence level of $99 \%$ between latent variables. Therefore, as it is obvious in the column of sig level, effect of variables on each other has been confirmed as the confidence level of $99 \%$.

\subsection{Fitness of research model}

Fitness of model means that observed variancecovariance matrix or the variance-covariance matrix predicted by model should have close values or should have good fitness. The closer the values of two matrixes are, the higher fitness of model would be. In structural equation modeling, one can trust in model estimations when the model has good fitness.

Table 6: Final model fit indices

\begin{tabular}{|c|c|c|c|}
\hline Indicator & $\begin{array}{c}\text { acceptable } \\
\text { value }\end{array}$ & value & result \\
\hline $\mathrm{X}^{2} / \mathrm{df}$ & $\mathrm{x} 2 / \mathrm{df} \leq 3$ & 2.88 & $\begin{array}{c}\text { Confirmed } \\
\text { model }\end{array}$ \\
\hline RMSEA & RMSEA<0.09 & 0.056 & $\begin{array}{c}\text { Confirmed } \\
\text { model }\end{array}$ \\
\hline GFI & GFI $>0.9$ & 0.92 & $\begin{array}{c}\text { Confirmed } \\
\text { model }\end{array}$ \\
\hline AGFI & AGFI $>0.85$ & 0.86 & $\begin{array}{c}\text { Confirmed } \\
\text { model }\end{array}$ \\
\hline CFI & $\mathrm{CFI}>0.90$ & 0.91 & $\begin{array}{c}\text { Confirmed } \\
\text { model }\end{array}$ \\
\hline IFI & $\mathrm{IFI}>0.90$ & 0.91 & $\begin{array}{c}\text { Confirmed } \\
\text { model }\end{array}$ \\
\hline
\end{tabular}

All fit indices used in the study show that the model has good fitness. Therefore, it could be found that the research model has high capability to measure main research variables. According to standard nature of model, Lisrel results are reliable.

\subsection{Testing main hypothesis using structural equation modeling (SEM)}

According to table 6, the results of analysis of research questions using findings of SEM are as follows:

Hypothesis: there is significant correlation between advertising and customer emotional reactions.

According to standard estimation of effect of advertising on emotional reactions of customers to
0.92 and values of $\mathrm{T}=10$ and $\mathrm{R} 2=0.84$; it could be found that at the significance level of $\mathrm{p}<0.01$, advertising can affect emotional reactions of customers. Hence, the hypothesis has been confirmed.

\section{Testing secondary hypotheses}

Hypothesis 1: there is significant correlation between relevant news of ads and customer emotional reactions.

At the first, to test the correlation between two variables, due to normality of research variables, Pearson correlation test has been used. In next step, univariate regression test has been used according to correlation between two variables to specify the intensity of interaction of the two variables.

Table 7: Correlation test of hypothesis 1

\begin{tabular}{cccc}
\hline & $\begin{array}{c}\text { customer } \\
\text { emotional } \\
\text { reactions }\end{array}$ & $\begin{array}{c}\text { number } \\
\text { of } \\
\text { sample }\end{array}$ & P-value \\
\hline $\begin{array}{c}\text { related news in } \\
\text { advertising }\end{array}$ & 0.524 & 386 & 0.001 \\
\hline
\end{tabular}

According to p-value lower than 0.05 , it could be mentioned that the correlation between two variables is significant. Hence, there is positive and significant correlation between relevant news in ads and customer emotional reactions. Therefore, it could be found that increase in relevant news in ads can lead to increased level of customer emotional reactions.

Table 8: Regression analysis of effect of relevant news in ads on customer emotional reactions

\begin{tabular}{ccccc}
\hline & $\begin{array}{c}\text { Observed } \\
\text { F value }\end{array}$ & $\begin{array}{c}p^{-} \\
\text {value }\end{array}$ & Beta & $\mathrm{R}^{2}$ \\
\hline $\begin{array}{c}\text { regression of } \\
\begin{array}{c}\text { relevant news in ads } \\
\text { on customer } \\
\text { emotional reactions }\end{array}\end{array}$ & 167.678 & 0.001 & 0.568 & 0.253 \\
\hline
\end{tabular}

Observed $\mathrm{F}$ value is equal to 167.678 and research question has been confirmed at the significance level of 0.001 and confidence level of 95\%. Therefore, as pvalue is lower than 0.05 , hence, the correlation between two variables was confirmed. It means that relevant news in ads can affect emotional reactions of customers. Beta coefficient to 0.568 shows that increase in relevant news of ads can increase emotional reactions of customers. The results show that $25.3 \%$ of variance of dependent variable (customer emotional reactions) can be discriminated by independent variable (relevant news of ads).

Hypothesis 2: there is significant correlation between brand strengthening in ads and customer emotional reactions. 
Table 9: Correlation test of hypothesis 2

\begin{tabular}{lccc}
\hline & $\begin{array}{c}\text { customer } \\
\text { emotional } \\
\text { reactions }\end{array}$ & $\begin{array}{c}\text { number } \\
\text { of } \\
\text { sample }\end{array}$ & P-value \\
\hline $\begin{array}{c}\text { brand promotion in } \\
\text { advertising }\end{array}$ & 0.427 & 386 & 0.001 \\
\hline
\end{tabular}

As p-value is lower than 0.05 , it could be mentioned that the correlation between two variables is significant. Hence, there is significant and positive correlation between brand strengthening in ads and customer emotional reaction. Hence, it could be found that increase in brand strengthening in ads can increase the level of emotional reactions of customers.

Table 10: Regression analysis of effect of brand strengthening in ads on customer emotional reactions

\begin{tabular}{lcccc}
\hline & $\begin{array}{c}\text { Observed } \\
\text { F value }\end{array}$ & $\begin{array}{c}p \text { - } \\
\text { value }\end{array}$ & Beta & $\mathrm{R}^{2}$ \\
\hline $\begin{array}{l}\text { regression of brand } \\
\text { strengthening in } \\
\text { ads on customer } \\
\text { emotional reactions }\end{array}$ & 78.658 & 0.001 & 0.425 & 0.178 \\
\hline
\end{tabular}

Observed $\mathrm{F}$ value is equal to 78.658 and research question has been confirmed at the significance level of 0.001 and confidence level of 95\%. Therefore, as pvalue is lower than 0.05 , hence, the correlation between two variables was confirmed. It means that brand strengthening in ads can affect emotional reactions of customers. Beta coefficient to 0.425 shows that increase in brand strengthening in ads can increase emotional reactions of customers. The results show that $17.8 \%$ of variance of dependent variable (customer emotional reactions) can be discriminated by independent variable (brand strengthening).

Hypothesis 3: there is significant correlation between entertainment in ads and customer emotional reactions

Table 11: Correlation test of hypothesis 3

\begin{tabular}{lccc}
\hline & $\begin{array}{c}\text { customer } \\
\text { emotional } \\
\text { reactions }\end{array}$ & $\begin{array}{c}\text { number } \\
\text { of } \\
\text { sample }\end{array}$ & P-value \\
\hline $\begin{array}{l}\text { Empathy in } \\
\text { advertising }\end{array}$ & 0.593 & 386 & 0.001 \\
\hline
\end{tabular}

As p-value is lower than 0.05 , it could be mentioned that the correlation between two variables is significant. Hence, there is significant and positive correlation between entertainment in ads and customer emotional reaction. Hence, it could be found that increase in entertainment in ads can increase the level of emotional reactions of customers.
Table 12: Regression analysis of effect of entertainment in ads on customer emotional reactions

\begin{tabular}{ccccc}
\hline & $\begin{array}{c}\text { Observed } \\
\text { F value }\end{array}$ & $p$-value & Beta & $\mathrm{R}^{2}$ \\
\hline $\begin{array}{c}\text { Regression of } \\
\text { entertainment in ads } \\
\text { on customer } \\
\text { emotional reactions }\end{array}$ & 278.121 & 0.001 & 0.499 & 0.374 \\
\hline
\end{tabular}

Observed $\mathrm{F}$ value is equal to 278.121 and research question has been confirmed at the significance level of 0.001 and confidence level of $95 \%$. Therefore, as pvalue was lower than 0.05 , the correlation between two variables was confirmed. It means that entertainment in ads can affect emotional reactions of customers. Beta coefficient to 0.499 shows that increase in entertainment in ads can increase emotional reactions of customers. The results show that $37.4 \%$ of variance of dependent variable (customer emotional reactions) can be discriminated by independent variable (entertainment in ads).

Hypothesis 4: there is significant correlation between sympathy in ads and customer emotional reactions

Table 13: Correlation test of hypothesis 4

\begin{tabular}{lccc}
\hline & $\begin{array}{c}\text { customer } \\
\text { emotional } \\
\text { reactions }\end{array}$ & $\begin{array}{c}\text { number of } \\
\text { sample }\end{array}$ & P-value \\
\hline $\begin{array}{l}\text { Empathy in } \\
\text { advertising }\end{array}$ & 0.666 & 386 & 0.001 \\
\hline
\end{tabular}

According to p-value lower than 0.05 , it could be mentioned that the correlation between two variables is significant. Hence, there is significant and positive correlation between sympathy in ads and customer emotional reaction. Hence, it could be found that increase in sympathy in ads can increase the level of emotional reactions of customers.

Table 14: Regression analysis of effect of sympathy in ads on customer emotional reaction

\begin{tabular}{ccccc}
\hline & $\begin{array}{c}\text { Observed } \\
\text { F value }\end{array}$ & $p$-value & Beta & $\mathrm{R}^{2}$ \\
\hline $\begin{array}{c}\text { Regression of } \\
\text { sympathy in ads } \\
\text { on customer } \\
\text { emotional } \\
\text { reaction }\end{array}$ & 322.25 & 0.001 & 0.578 & 0.342 \\
\hline
\end{tabular}

Observed $\mathrm{F}$ value is equal to 322.43 and research question has been confirmed at the significance level of 0.001 and confidence level of $95 \%$. Therefore, as pvalue was lower than 0.05 , the correlation between two variables was confirmed. It means that empathy in ads can affect emotional reactions of customers. Beta coefficient to 0.578 shows that increase in sympathy in ads can increase emotional reactions of customers. The results show that $34.2 \%$ of variance of dependent 
variable (customer emotional reactions) can be discriminated by independent variable (sympathy in ads).

Hypothesis 5: there is significant correlation between familiarity with ads and customer emotional reactions

Table 15: Correlation test of hypothesis 5

\begin{tabular}{cccc}
\hline & $\begin{array}{c}\text { customer } \\
\text { emotional } \\
\text { reactions }\end{array}$ & $\begin{array}{c}\text { number } \\
\text { of } \\
\text { sample }\end{array}$ & P-value \\
\hline $\begin{array}{c}\text { familiarity with } \\
\text { advertising }\end{array}$ & 0.519 & 386 & 0.001 \\
\hline
\end{tabular}

As p-value is lower than 0.05 , it could be mentioned that the correlation between two variables is significant. Hence, there is significant and positive correlation between familiarity with ads and customer emotional reaction. Hence, it could be found that increase in familiarity with ads can increase the level of emotional reactions of customers.

Table 16: Regression analysis of the effect of familiarity with ads on customer emotional reactions

\begin{tabular}{ccccc}
\hline & $\begin{array}{c}\text { observed } \\
\text { F value }\end{array}$ & $p$-value & Beta & $\mathrm{R}^{2}$ \\
\hline $\begin{array}{c}\text { regression } \\
\text { analysis of the } \\
\text { effect of } \\
\text { familiarity with } \\
\text { ads on customer } \\
\text { emotional } \\
\text { reactions }\end{array}$ & 110.352 & 0.001 & 0.498 & 0.195 \\
\hline
\end{tabular}

Observed $\mathrm{F}$ value is equal to 110.352 and research question has been confirmed at the significance level of 0.001 and confidence level of $95 \%$. Therefore, as pvalue was lower than 0.05 , the correlation between two variables was confirmed. It means that familiarity with ads can affect emotional reactions of customers. Beta coefficient to 0.498 shows that increase in familiarity with ads can increase emotional reactions of customers. The results show that $19.5 \%$ of variance of dependent variable (customer emotional reactions) can be discriminated by independent variable (familiarity with ads).

Hypothesis 6: there is significant correlation between confusion in ads and customer emotional reactions.

Table 17: Correlation test of hypothesis 6

\begin{tabular}{cccc}
\hline & $\begin{array}{c}\text { customer } \\
\text { emotional } \\
\text { reactions }\end{array}$ & $\begin{array}{c}\text { number } \\
\text { of } \\
\text { sample }\end{array}$ & P-value \\
\hline $\begin{array}{c}\text { confusion in } \\
\text { advertising }\end{array}$ & -0.505 & 386 & 0.001 \\
\hline
\end{tabular}

As p-value is lower than 0.05 , it could be mentioned that the correlation between two variables is significant. Hence, there is significant and positive correlation between confusion in ads and customer emotional reaction. Hence, it could be found that increase in confusion in ads can increase the level of emotional reactions of customers.

Table 18: Regression analysis of the effect of confusion in ads on customer emotional reactions

\begin{tabular}{ccccc}
\hline & $\begin{array}{c}\text { Observed } \\
\text { F value }\end{array}$ & $p$-value & Beta & $\mathrm{R}^{2}$ \\
\hline $\begin{array}{c}\text { regression of } \\
\text { confusion in ads } \\
\text { on customer } \\
\text { emotional } \\
\text { reactions }\end{array}$ & 112.352 & 0.001 & -0.505 & 0.275 \\
\hline
\end{tabular}

Observed $\mathrm{F}$ value is equal to 112.352 and research question has been confirmed at the significance level of 0.001 and confidence level of $95 \%$. Therefore, as pvalue was lower than 0.05 , the correlation between two variables was confirmed. It means that confusion in ads can affect emotional reactions of customers. Beta coefficient of -0.505 shows that increase in confusion in ads can increase emotional reactions of customers. The results show that $27.5 \%$ of variance of dependent variable (customer emotional reactions) can be discriminated by independent variable (confusion in ads).

Hypothesis 7: there is significant correlation between customer pleasant emotional reactions to ads and advantage-based value.

Table 19: Correlation test of hypothesis 7

\begin{tabular}{cccc}
\hline & $\begin{array}{c}\text { advantage- } \\
\text { based value }\end{array}$ & $\begin{array}{c}\text { number of } \\
\text { sample }\end{array}$ & P-value \\
\hline $\begin{array}{c}\text { customer pleasant } \\
\text { emotional } \\
\text { reactions }\end{array}$ & 0.461 & 386 & 0.001 \\
\hline
\end{tabular}

As p-value is lower than 0.05 , it could be mentioned that the correlation between two variables is significant. Hence, there is significant and positive correlation between customer pleasant emotional reactions and advantage-based value. Hence, it could be found that increase in customer pleasant emotional reactions can increase the level of advantage-based value.

Table 20: Regression analysis of the effect of customer pleasant emotional reactions on advantage-based value

\begin{tabular}{ccccc}
\hline & $\begin{array}{c}\text { observed } \\
\text { F value }\end{array}$ & $p$-value & Beta & $\mathrm{R}^{2}$ \\
\hline $\begin{array}{c}\text { regression of } \\
\text { customer } \\
\text { pleasant } \\
\text { emotional } \\
\text { reactions on } \\
\text { advantage-based } \\
\text { value }\end{array}$ & 103.369 & 0.001 & 0.389 & 0.212 \\
\hline
\end{tabular}


Observed $\mathrm{F}$ value is equal to 103.369 and research question has been confirmed at the significance level of 0.001 and confidence level of $95 \%$. Therefore, as $\mathrm{p}$ value was lower than 0.05 , the correlation between two variables was confirmed. As p-value is lower than 0.05 , it could be mentioned that the correlation between two variables is significant. It means that customer pleasant emotional reactions can affect advantage-based value. Beta coefficient of 0.389 shows that increase in customer pleasant emotional reactions can increase advantage-based value. The results show that $21.2 \%$ of variance of dependent variable (advantage-based value) can be discriminated by independent variable (customer pleasant emotional reactions).

Hypothesis 8: there is significant correlation between customer pleasant emotional reactions and their hedonic value.

At the first, to test the correlation between two variables, due to normality of research variables, Pearson correlation test has been used. In next step, univariate regression test has been used according to correlation between two variables to specify the intensity of interaction of the two variables.

Table 21: Correlation test of hypothesis 8

\begin{tabular}{cccc}
\hline P-value & $\begin{array}{c}\text { number of } \\
\text { sample }\end{array}$ & $\begin{array}{c}\text { pleasant } \\
\text { value }\end{array}$ & \\
\hline 0.014 & 386 & 0.584 & $\begin{array}{c}\text { customer pleasant } \\
\text { emotional reactions }\end{array}$ \\
\hline
\end{tabular}

As p-value is lower than 0.05 , it could be mentioned that the correlation between two variables is significant. Hence, there is significant and positive correlation between customer pleasant emotional reactions and hedonic value. Hence, it could be found that increase in customer pleasant emotional reactions can increase the level of hedonic value.

Table 22: Regression analysis of the effect of customer pleasant emotional reactions on their hedonic value

\begin{tabular}{ccccc}
\hline & $\begin{array}{c}\text { observed } \mathrm{F} \\
\text { value }\end{array}$ & $p$-value & Beta & $\mathrm{R}^{2}$ \\
\hline $\begin{array}{c}\text { regression of } \\
\text { customer } \\
\text { pleasant }\end{array}$ & & & & \\
$\begin{array}{c}\text { emotional } \\
\text { reactions on } \\
\text { their hedonic } \\
\text { value }\end{array}$ & 448.198 & 0.001 & 0.458 & 0.341 \\
\hline
\end{tabular}

Observed $\mathrm{F}$ value is equal to 448.198 and research question has been confirmed at the significance level of 0.001 and confidence level of $95 \%$. Therefore, as pvalue was lower than 0.05 , the correlation between two variables was confirmed. As p-value is lower than 0.05 , it could be mentioned that the correlation between two variables is significant. It means that customer pleasant emotional reactions can affect hedonic value. Beta coefficient of 0.458 shows that increase in customer pleasant emotional reactions can increase hedonic value. The results show that $0.341 \%$ of variance of dependent variable (hedonic value) can be discriminated by independent variable (customer pleasant emotional reactions).

\section{Conclusion}

The present study has investigated the effect of advertising on customer emotional reaction in Parsian Bank Branches in Tehran. Statistical population in this study consists of all customers of Parsian Bank Branches in Tehran. Using Morgan table, 146 people were selected as sample using simple random sampling. The results obtained from data analysis showed that there is significant correlation between advertising and customer emotional reactions. Therefore, makers of advertising teasers should consider their target group and take measure to increase their emotional reactions based on their personality traits. The results of this study are in consistence with findings of Malik et al (2014), Sharma et al (2014), Sonokosare (2013), Sin Han et al (2011), Tee Sang (2004), Ghoochani et al (2013), Niroomand et al (2012). The scholars showed in their results that advertisements can affect emotional reactions and purchase behavior of consumer. Moreover, the results show the correlation between relevant news in ads and customer emotional reactions. Marketing and business managers of Parsian Bank should induct their strengths directly and indirectly to customer while making advertising teasers to enhance emotional reactions of customer. The results of this study are in consistence with findings of Sin Han et al (2011), Tee Sang (2004). The results of the study show significant correlation between brand strengthening in ads and customer emotional reactions. Parsian Bank branches in Tehran should introduce their services in just way and without exaggeration, so that negative advertising can't cause boredom of customer towards services. The results of this study are in consistence with findings of Sin Han et al (2011). Other results show correlation between entertainment in ads and customer emotional reactions. Business and marketing managers of this bank tend to make ads happy, so that customers don't feel boredom with watching ads several times a day, as their services have no special age range. The results of this study are in consistence with findings of Sin Han et al (2011). The results show correlation between sympathy in ads and customer emotional reactions. Ads should be made in such way that they can show daily problems in real way, so that customers feel need to use bank services after watching ads. These results are in consistence with findings of Sin Han et al (2011) and Tee Sang (2004).

The results obtained from data analysis show significant correlation between familiarity with ads and customer emotional reactions. Therefore, ads of 
the brand should be continuously exposed to looks of customers to make customer familiar with the brand. Results of this study are in consistence with findings of Sin Han et al (2011).

The results of the study show correlation between confusion in ads and customer emotional reactions. Managers of making advertising teasers should adjust video content of ads to an extent that audiences don't be confused after watching the ads. This is because; this can cause reduction of purchase behavior of customer. The results of this study are in consistence with findings of Sin Han et al (2011).

The results show correlation between enjoyable emotional reactions of customers to ads and advantage-based value. The ads should make sense of comfort, happiness of customer and hope in customers. The results of the study are in consistence with findings of Sin Han et al (2011) and Jaxel (2007).

The results show significant correlation between pleasant customer emotional reactions to ads and their hedonic value. Managers should make the feeling in these customers that using this service can double the joy of purchase for them through providing comfort and happy environments in ads. The results of the study are in consistence with findings of Sin Han et al (2011), Jaxel (2007).

\section{References}

Dehdashti Sh, Z, Liakhei Aniak, N (2009) The Effectiveness of Internet Advertising on behavior of Consumers of Goods and Computer Services, Improvement Management Studies, No 60, 115-124.

Ghoochani, F, Hashemnia, Sh, Iqbal, R (2013) The Effect of Media Types as One of the Marketing Strategies in the Driving Behavior of a Riding Car, Journal of Marketing Management, No. 20, 103-120.

Niroomand, L, Tajik Ismaili S, Malekian, N, Shahkouhi, S (2012) Investigating the Relationship between Television Advertising and Consumerism, Media Studies, seventh year, No. 17, 43-54.
Venus, D, Saffarian, M (2005) Banking Service Marketing Methods for Iranian Banks, Tehran, Iran.

Dehdashti; Sh (2009). The Effectiveness of Internet Advertising on Consumer Goods and Computer Services, Journal of Improvement Management, No. 60, ScientificPromotion Page - From, 115-124

Behnam M, M Goodarzi, Mehrzad H, (2015). The effect of advertising gravity on future intentions and attitudes towards consumer advertising in sports services, Sports Management Studies No. 30. August 2015, pp.35-54

Altuna, O. K., \& Konuk, F. A. (2009). Understanding consumer attitudes toward mobile advertising and its impact on consumers' behavioral intentions: a crossmarket comparison of United States and Turkish consumers. International Journal of Mobile Marketing, 4(2), 43e51.

Chen, I. C., \& Hu, S. C. (2012). Gender differences in shoppers' behavioural reactions to ultra-low price tags at online merchants. Electronic Commerce Research, 12(4), $485 \mathrm{e} 504$

Chen, C.F. and Chen, F.S ((2010).Experience quality, perceived value, satisfaction and behavioral intentions for heritage tourists. Tourism Management.

Ho, S. Y. (2012). The effects of location personalization on individuals' intention to use mobile services. Decision Support Systems, 53(4), 802e812

Hsu, C. L., \& Lin, J. C. C. (2008). Acceptance of blog usage: the roles of technology acceptance, social influence and knowledge sharing motivation. Information \& Management, 45(1), 65e74

Merisavo, M., Kajalo, S., Karjaluoto, H., Virtanen, V., Salmenkivi, S., Raulas, M., et al. (2007). An empirical study of the drivers of consumer acceptance of mobile advertising. Journal of Interactive Advertising, 7(2), 41e50

Smith, R. E., Mackenzie, S. B., Yang, X., Buchholz, L. M., \& Darley, W. K. (2007). Modeling the determinants and effects of creativity in advertising. Marketing Science, 26(6), 819e833.Ha HY., John J., Janda S. \& Muthaly S. 2011 The effects of advertising spending on brand loyalty in services. European Journal of Marketing, 45(4):673-691.

Buil I., Chernatony L. \& Martinez E. 2011. A cross-national validation of the consumer-based brand equity scale. Journal of Product \& Brand Management, 17(6):384-392. 